\title{
Factors Influencing ICT adoption by Faculty in the Teaching Learning Process
}

\author{
Rupa Sarkar $^{*}$ and Jacqueline Kareem ${ }^{\dagger}$
}

\begin{abstract}
This study seeks to find out the extent of different influence factors have on the attitude of the Faculty towards adoption of Information and Communication Technology (ICT). Teachers who have differences in demographical variables may also differ in their adaptability tendencies. Survey methodology was facilitatedusing questionnaires which were given to 300 College teachers randomly chosen from different colleges working under different types of management in the city of Bangalore. 287 questionnaireswere returned. Out of these, 250 were considered complete and chosen as our study sample. Oscarson's 'Adoption to proneness' scale was adopted with minor modifications in language and items based on available literature. A pilot study was done with 50 sample size for checking validity. After satisfactory results came, the adopted questionnaire was given to 300 respondents. A personal data form was also given to gather the personal details of these respondents regarding their age, gender, department of work, teaching level, teaching workload per week, years of experience and academic qualification. The analysis shows significant differences in influence in adoption of ICT among age groups, department of work and teaching
\end{abstract}

\footnotetext{
* School of Education, Christ University, Bengaluru, India; rupasneha72@gmail.com

$\dagger$ School of Education, Christ University, Bengaluru, India, jacqueline.loleta@christuniversity.in
} 
levels. Academic qualification didn't show any significant difference. The implications of the findings will help in formulation of tailor-made ICT in-service training and orientation programmes for teachers who are digital immigrants and teachers who are digital natives as well.

Keywords: ICT usage, Faculty attitude towards ICT, Faculty support, Barriers to ICT.

\section{Introduction}

The implementation of ICT in the realm of education is not a very recent phenomena, it in fact is the need of the hour. Some of the major concerns though relate to making the process from teacher centered classrooms to ICT oriented classrooms smoother and removing the barriers of acceptance, thereby involving each one of the stakeholders who are a part of this process. ICT has touched almost all the spheres of all our day to day activities. It has brought the world closer, made each country interdependent, and drawn the attention of the Governments, Corporates, Academia and masses at large. It is probably the most radical invention of this century.

\section{ICT usage}

Information and Communication Technologies refers to technologies that provide access to information through telecommunications. It focuses mainly on any product that will store, retrieve, manipulate, transmit or receive information electronically in digital form. For this study, ICT usage is confined to Email, online forums for discussion, internet use for instruction material, MS office, simulations of CAD, SIM,GIS, online and offline applications of multimedia for classroom and amount of use in teaching.

\section{Faculty Attitude towards ICT usage}

Attitude is "A disposition to respond favourably or unfavourably to an object, person, institution or event" (Ajzen, 2005). Performance is determined substantially by Attitude. Disposition of Teaching staff towards a technique (ICT in Pedagogical Practices) can be affected by personal philosophies, cognitive 
comfort zones, and work beliefs. It can range from feeling intimidated and threatened to excitement and confidence.

In this study Faculty attitude towards ICT usage includes attitude towards adoption tendencies, amount of ICT usage in instruction, amount of support in ICT services, barriers to ICT usage, feelings towards ICT, and amount of available professional development services.

\section{Faculty support}

Factors like availability of instructional and technical support which are further dependent on the frequency of need for these supports that arise from the perspective of Faculty constitute the faculty support concept in this study. It determines the amount of usage of ICT based on these support.

\section{Barriers to ICT}

Dimensions related to access to computers in laboratories, classrooms, staffroom, internet connectivity, backdated technical infrastructure, lack of ICT skills, time shortage to acquire these skills, management rules for internet usage inside classroom, lack of experience and training in using ICT in pedagogy constitute the barriers to ICT in this study.

\section{MHRD policy on Teacher empowerment through Digital Literacy}

The National Mission on Education through Information and Communication Technology (NMEICT) has been envisaged as a Centrally Sponsored Scheme to leverage the potential of ICT, in teaching and learning process for the benefit of all the learners in Higher Education Institutions inanytime anywhere mode. This was expected to be a significant intervention in enhancing the Gross Enrolment Ratio (GER) in Higher Education by five percentage points during the XI Five Year Plan. It seeks to bridge the digital divide, i.e. the gap in the skills to use computing devices for the purpose of teaching and learning among urban and rural teachers/learners in Higher Education domain and empower those, who have hitherto remained untouched by the digital revolution and have not been able to join the mainstream of the knowledge economy. 


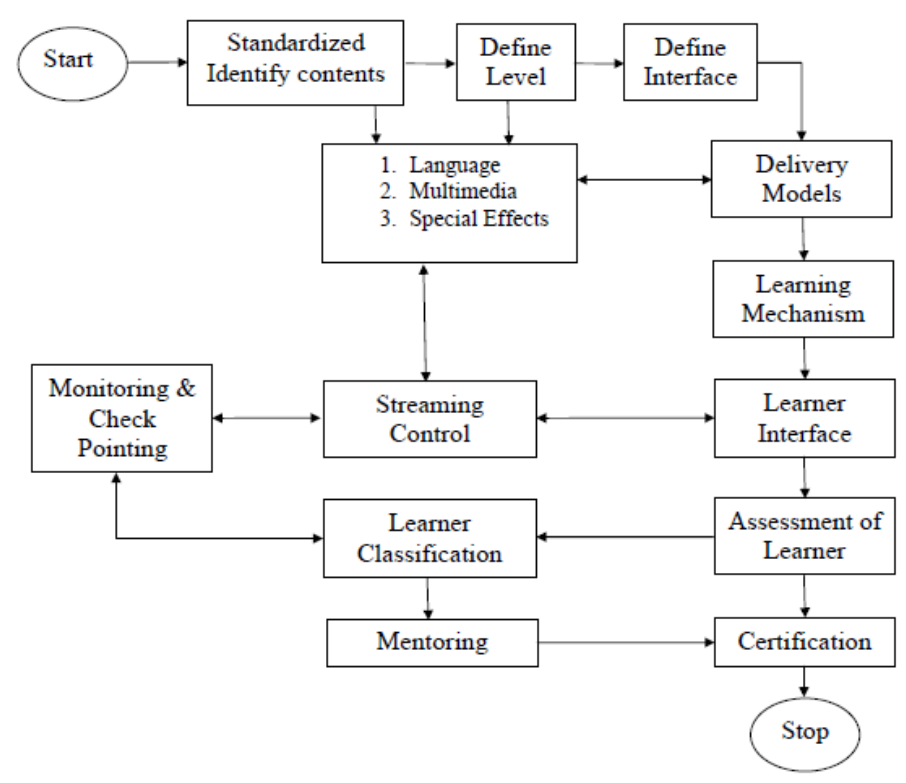

Fig 1: Flowchart for Teacher Empowerment through Digital Literacy

Source: http://mhrd.gov.in/sites/upload_files/mhrd/files/upload_document/MissionDocument.pdf

\section{Need for Faculty Attitude Surveys}

- Focusing of Employee Development Programs

- Enhancing Management/Employee Relations

- Training Needs Assessment

- Evaluation of Training

- Organizational Climate Survey

This process can also be a motivator of performance since it shows the employee that their opinions and views are considered important and provides a direct means of assessing Faculty opinions that would otherwise go unreported.

\section{Need for the Study}

Teaching staff is the most valuable asset for any Educational Institution. Their attitude towards an innovative change, which has become indispensable, matters the most when crucial decisions have to be made in the Teaching-Learning Process.

The location of the study, city of Bangalore is the IT hub of modern India. The city has seen a huge influx of people resulting in 
mushroom growth of HEIs. Each one of them is trying to achieve excellence. Incorporating ICT has become essential yet there is a need to remove all barriers in the process so that the teaching staff has a smooth transition during this phase of change. The objective of the study was to find out the differences in the Attitude towards ICT based on demographic variables. Knowing these differences would help plan training and placements of the right person in the right place.

\section{Assumption}

This study is based on the assumption that the respondents had been truthful while answering the questionnaire given to them for the survey.

\section{Ethical Consideration}

The Respondents were given the assurance of confidentiality of information to be used only for Research purposes by the Researcher. Names of Institution and individual participants wouldn't be revealed in the course of the study.

\section{Demographic Variables}

Age, Gender, Department of work, Academic Qualification, Level at which teaching, Hours of teaching load per week and Teaching Experience.

\section{Methodology}

\section{Objectives of the study:}

a. The measure of Faculty adoption proneness

b. The measure of Faculty usage of ICT in Instruction

c. The amount of support in ICT services Faculty can avail according to their perception

d. How Faculty perceives the barriers to ICT usage in Teaching learning process

e. The amount of professional development services offered to Faculty

f. What are the differences that exist between Faculty demographics and ICT usage 


\section{Tool for the study}

The Oscarson, 'Adoption to Proneness Scale' was used for this study. This scale was selected based on review of related literature. Modifications were done in the terminology and some items, then a pilot study was undertaken to ensure its relevance in the context. The questionnaire after modification was first sent to 50 respondents with a return rate of $87 \%$ and was found to be appropriate for this study.

A random sampling procedure was adopted to select 250 Teachers from different colleges of Bangalore. 126 male and 124 female respondents were selected out of the 287 online questionnaires that were completed and returned. 45 of them were from Pure Science Department, 52 from Social Science \& Humanities, 65 from Commerce, 28 from Computer, 32 from Management studies, 28 from Hospitality \& Fashion.

Table 1: Department summary of Gender of Respondents

\begin{tabular}{lcccc}
\hline Name of Department & Frequency & Percentage & Males & Females \\
Pure Science & 45 & $18 \%$ & 25 & 20 \\
Social Science \& & 52 & $20.8 \%$ & 22 & 30 \\
Humanities & & & & \\
Commerce & 65 & $26 \%$ & 35 & 30 \\
Computer Science & 28 & $11.2 \%$ & 17 & 11 \\
Management Studies & 32 & $12.8 \%$ & 15 & 17 \\
Hospitality \& Fashion & 28 & $11.2 \%$ & 12 & 16 \\
\hline
\end{tabular}

Social Science and Humanities \& Commerce department female respondents were highest in number followed by Pure Sciences, Management Studies, Hospitality \& Fashion and Computer Science in that order.

Attitude was measured using Oscarson's 'Adoption to Proneness' Scale after modifications.

Questionnaire is of the form of a Likert Scale with 46 items on a 6 point scale from 'No, never' being 1 and 'Yes, always' being 6 . On the whole the scale has 6 parts out of which 4 are based on Likert scale. Part VI is quantity (Hours) based. Part III is based onBi-polar adjectives with a range of 7 levels ranging from: 
1. Extremely, 2.Quite, 3.Slightly, 4.Neutral, 5.Slightly, 6.Quite, 7.Extremely

\section{Reliability of the tool}

Table 2: Reliability analysis of the tool

\begin{tabular}{lcc}
\hline \multicolumn{1}{c}{ Factors } & $\begin{array}{c}\text { Number of } \\
\text { items }\end{array}$ & $\begin{array}{c}\text { Cronbach's Alpha } \\
\text { Values }\end{array}$ \\
Adoption Tendency & 14 items & 0.781 \\
ICT Usage & 7 items & 0.809 \\
Faculty Support Services & 5 items & 0.738 \\
ICT Barrier & 14 items & 0.811 \\
Faculty Professional & 6 items & 0.799 \\
Development & & \\
bi-polar adjectives for ICT usage & 4 items & 0.741 \\
Cronbach's Alpha for the full & & 0.742 \\
scale & & \\
\hline
\end{tabular}

Validity of the tool

Principal CFA was used to assess convergent and discriminant validity.

Table 3: Factor loadings after tool modification

\begin{tabular}{lcccccc}
\hline $\begin{array}{c}\text { Mean of Overall } \\
\text { Loadings }\end{array}$ & $\begin{array}{c}\text { Part I } \\
\text { Items }\end{array}$ & $\begin{array}{c}\text { Part II } \\
\text { Items }\end{array}$ & $\begin{array}{c}\text { Part III } \\
\text { Items }\end{array}$ & $\begin{array}{c}\text { Part IV } \\
\text { Items }\end{array}$ & $\begin{array}{c}\text { Part V } \\
\text { Items }\end{array}$ & $\begin{array}{c}\text { Part VI } \\
\text { Items }\end{array}$ \\
Part I Items & 0.784 & 0.235 & 0.312 & 0.301 & 0.271 & 0.256 \\
Part II Items & 0.023 & 0.851 & 0.217 & 0.051 & 0.288 & 0.226 \\
Part III Items & 0.127 & 0.072 & 0.769 & 0.132 & 0.341 & 0.318 \\
Part IV Items & 0.198 & 0.140 & 0.171 & 0.879 & 0.091 & 0.042 \\
Part V Items & 0.231 & 0.258 & 0.025 & 0.125 & 0.881 & 0.148 \\
Part VI Items & 0.159 & 0.311 & 0.173 & 0.117 & 0.146 & 0.789 \\
\hline
\end{tabular}

It shows that the internal convergence (High correlation) is established among items of each part of the tool. It also shows that the internal divergence (Low correlation) is established among items of different parts of the tool. 


\section{Analysis and discussion}

Descriptive analysis, t-test, one way ANOVA, correlation were used.

Findings of the Faculty Attitude:

Table 4: Faculty Attitude Findings of the Adoption to Proneness scale

\section{Faculty Attitude regarding}

\section{Part I- Adoption Tendency}

Optimism towards change

Willingness to put extra effort

Willingness to take risk

Adoption followed after lot of reflection

Freedom to initiate innovation

Persistence in sticking to change

Make effort to read about innovation in

education

Willingness to open a discussion on your

suggestion for change with colleagues

Try to network with other institutions who have

made interesting changes

Tendency to bring new ideas in front of

colleagues and department

Tendency to question pedagogies

Perception about being encouraged to innovate

by Head of the Department

Perception about being encouraged to innovate

by Administration Head

Awareness about recent Researches in Education

\section{Part II-Usage of ICT}

Email

Online forums for discussion

Internet use for instruction material

MS office

Simulations of CAD, SIM, GIS

Multimedia applications for classroom (Online \&

Offline)

Amount of Use in Teaching

PART IV-Faculty Support Services

Availability of Instructional Support

Availability of Technical Support
Mean

4.2

3.8

4.0

3.7

3.8

3.4

4.2

4.6

0.94 


\begin{tabular}{lll}
\hline Frequency of Need for Instructional Support & 4.3 & 0.95 \\
Frequency of Need for Technical support & 4.7 & 1.24 \\
Amount of use of ICT after receiving Support (if & 4.0 & 0.88 \\
any) & & \\
Part V-ICT Barriers & 4.1 & 0.79 \\
Frequency of facing barriers while Teaching & 3.8 & 0.72 \\
Access to computers in laboratories & 3.4 & 0.77 \\
Access to computers in classrooms & 3.2 & 0.69 \\
Access to computers with internet connection in & & \\
classroom & 4.2 & 0.82 \\
Backdated technology & 4.3 & 0.87 \\
Insufficient Software support & 4.1 & 0.85 \\
Access to Computer with internet connection in & & \\
staffroom & 3.1 & 0.75 \\
Mobile Access and permission for classroom & & \\
usage & 3.9 & 1.23 \\
Technical support accessibility & 3.7 & 0.91 \\
Instructional support accessibility & 4.3 & 0.69 \\
Lack of ICT skills & 4.4 & 0.71 \\
Lack of time to acquire ICT skills & 4.1 & 0.67 \\
Lack of Experience in ICT pedagogy & 3.8 & 0.92 \\
Lack of Training in ICT &
\end{tabular}

Part III- Feelings about using IT

\begin{tabular}{lcc}
\hline \multicolumn{1}{c}{ Bipolar Adjectives } & Mean of Attitude towards IT & SD \\
Good- Bad & 2.8 & 1.20 \\
Meaningful-Meaningless & 1.5 & 1.15 \\
Pleasant-Unpleasant & 2.4 & 0.95 \\
Fair-Unfair & 2.1 & 0.92 \\
\hline
\end{tabular}

Part VI-Faculty Professional Development

\begin{tabular}{lcc}
\hline \multicolumn{1}{c}{ Courses offered } & Mean of \\
in year 2014-2015 & $\begin{array}{c}\text { Number of } \\
\text { Hours(After } \\
\text { Rounding) }\end{array}$ & $\begin{array}{c}\text { Percentage of } \\
\text { Respondents } \\
\text { Attended }\end{array}$ \\
In house training from Department & 20 & $93.1 \%$ \\
Other Universities & 6 & $74 \%$ \\
Corporates & 4 & $29 \%$ \\
Accreditation/Supervisory Agencies & 7 & $40.5 \%$ \\
Government Notice & 15 & $32.2 \%$ \\
Technical Education Department & 10 & $68.7 \%$ \\
\hline
\end{tabular}


Findings for objective (a): The measure of Faculty adoption proneness

Item 9 has the highest Mean of 4.6 indicating that 'Try to network with other institutions who have made interesting changes' ranges between usually to almost always followed by item 13 'Perception about being encouraged to innovate by Administration Head' with a mean of 4.5 , item $8,10,11,14,12,6 \& 3$ and 5,7 in that order. The Standard Deviation is highest in item 10 followed by 1, 2, 3 \& 12, 7, 13, 6, 11 and 14 .

\section{Educational Implications}

- Networking between Institutions who are making interesting innovations as part of their best practices has to gain momentum among HEI in the form of integrated workshops, interdisciplinary resource exchange, infrastructural sharing and so on.

- The encouragement from administration heads holds key motivational factors among faculty to take initiatives. One way of doing that may be felicitating some of the faculty members who have undergone some training in ICT or some sort of perquisites as reinforcement to teachers to incorporate ICT in their TLP.

- The setting up of discussion platforms on a regular basis among colleagues with assignment of a moderator will be beneficial since that item ranks high in favouring adoption proneness.

- Sharing of university and college magazines and journals which are circulated free among faculty can expose them more to the recent action researches taken in the classrooms with the help of ICT.

- Freedom to innovate should be extensively provided

Findings for objective (b): The measure of Faculty usage of ICT in Instruction

Item 1 'Email' has highest mean of 4.8 indicating frequently to almost always followed by item 7 'Amount of Use in Teaching', item 3, 2, 4, 6 and item 5 in the range infrequently to frequently. The highest SD was observed in item 2 'Online forums for 
discussion' followed by item 7 'Amount of Use in Teaching', item 3, 4, 1, 6 and item 5 in that order.

\section{Educational Implications}

- Training workshops for orientation to CAD/GIS/SIM which run as factors which are most infrequently used have to be incorporated in all types of colleges and Universities.

- Internet access for preparation of Instructional material has to be freely available in faster speeds of broadband to faculty even inside classrooms to be able to deliver in the form intended. Staffrooms need to be Wi-Fi enabled so as to have research inclination among faculty who can deliberate whenever they have opportunity to do so.

- Multimedia applications in Instructional materials should be encouraged and some sort of bonus points awarded to teachers who incorporate relevant modules in the TLP.

Findings for objective (c): The amount of support in ICT services Faculty can avail according to their perception

Item 4 'Frequency of Need for Technical support' has the highest mean of 4.7 indicating frequently to always followed by item 3 'Frequency of Need for Instructional Support' showing mean 4.3, item 5, 1 and item 2 in that order. Item 4 has the highest SD of 1.24 followed by item 3 with 0.95 , item 1,2 and 5 in that order.

\section{Educational Implications}

- The frequency of Instructional support need is very high so there is a need of a constant backup from the concerned department.

- The frequency of technical support required is also very high so the infrastructure readiness of the Institution should be user friendly and that will motivate more and more teachers to introduce ICT in their Instructional methods.

- The presence of in-house support personnel within each department can work wonders for teachers who have just 
started with introduction of ICT in their everyday classroom affairs.

Findings for objective (d): How Faculty perceives the barriers to ICT usage in teaching learning process

Item 12 'Lack of time to acquire ICT skills' has the highest mean of 4.4 frequently indicating to always followed by item 11 , six at mean 4.3 , items $5,2,13,7,1,9,2,14,10,3$, 4and 8 in that order. Item 9 'Technical support accessibility' has the highest SD followed by 14, $10,6,7,5,1,8,3,2,12,11,4$ and 13 in that order.

\section{Educational Implications}

- Lack of time to acquire ICT skills is seen as a major deterrent for teachers. A set of chosen faculty should be allowed non-class hours for attending in-service training workshops both inside and outside campus.

- Insufficient software support seems to be a major barrier for ICT adoption. Institutions should make available costly software on trial basis first to a group of teachers who can learn and later become master trainers for the rest of the staff.

- First priority should be to bring all the teachers to a common attainable level of ICT skills and then proceed for further upgradation to higher levels.

- Continuous support of personnel in case of ICT usage facing difficulty at all levels would instil a lot of confidence in teachers who are newly adapting to innovative methods.

- Any amount of ridicule can do unimaginable harm in the adoption extent.

- Access to fast and free internet in the classroom, staffroom, Laboratories, Language Labs, Administration offices can bring in enormous amount of adoption enhancement. 
Findings for objective (e): The amount of professional development services offered to Faculty

$93.1 \%$ of respondents attended approximately 20 hours of In house training provided from Department. $74 \%$ of respondents attended courses/training offered by other universities on an average of approximately 6 hours. $68.7 \%$ respondents attended about 10 hours of courses offered by Technical Education Department. 40.5\% respondents attended about 7 hours of courses offered by Accreditation/Supervisory Agencies. 32.2\% respondents attended about 15 hours of courses offered due to Government notice. 29\% respondents attended courses offered by corporates for around 4 hours.

\section{Educational Implications}

- The number of hours that was offered as in-service training to existing teachers was maximum and was availed by the highest majority of respondents.

- Percentage was high for training sessions given by other Universities also but the hours offered was very less. IntraInstitutional Resource exchange can be worked upon for betterment.

- A very high percentage also attended courses offered by the Technical Department.

\section{Inferential Statistics}

Findings for objective (f): Differences that exist between selected Faculty demographics and ICT usage in teaching learning process

- One way ANOVA Summary by extent of ICT usage and Department of Work of Respondents

- Null Hypothesis: There is no significant difference in the means of ICT Usage among different groups of respondents from different departments of work.

- Alternate Hypothesis: There is a significant difference in the means of ICT Usage among different groups of respondents from different departments of work. 
Table 5: ANOVA summary by extent of ICT usage and Department of Work of Respondents

\begin{tabular}{lcccc}
\hline \multicolumn{1}{c}{ Source } & SS & df & MS & F \\
Between Groups & 38 & 5 & 7.60 & 5.00 \\
Within Groups & 371.4 & 244 & 1.52 & \\
Total & 409.4 & 249 & & \\
\hline
\end{tabular}

* $\mathrm{p}<.05$

There is a significant difference in the means between ICT usage and different departments of Respondents. So the Null Hypothesis is rejected and alternate Hypothesis is accepted.

- One way ANOVA Summary by extent of ICT usage and age group of Respondents

- Null Hypothesis: There is no significant difference in the means of ICT Usage among different age groups of respondents.

- Alternate Hypothesis: There is a significant difference in the means of ICT Usage among different age groups of respondents.

Table 6: ANOVA Summary by extent of ICT usage and age group of Respondents

\begin{tabular}{ccccc}
\hline Source & SS & df & MS & F \\
Between Groups & 45.1 & 5 & 9.02 & 6.35 \\
Within Groups & 345.7 & 244 & 1.42 & \\
Total & 390.8 & 249 & & \\
\hline
\end{tabular}

${ }^{*} \mathrm{p}<.05$

There is a significant difference in the means between ICT usage and different age groups of Respondents. So the Null Hypothesis is rejected and alternate Hypothesis is accepted.

- One way ANOVA Summary by extent of ICT usage and level of teaching of Respondents

- Null Hypothesis: There is no significant difference in the means of ICT Usage among respondents teaching at different levels. 
- Alternate Hypothesis: There is a significant difference in the means of ICT Usage among respondents teaching at different levels.

Table 7: ANOVA Summary by extent of ICT usage and different levels of teaching of Respondents

\begin{tabular}{lcccc}
\hline \multicolumn{1}{c}{ Source } & SS & df & MS & F \\
Between Groups & 38.3 & 2 & 19.15 & 13.49 \\
Within Groups & 349.9 & 247 & 1.42 & \\
Total & 388.2 & 249 & & \\
\hline
\end{tabular}

${ }^{*} \mathrm{p}<.05$

There is a significant difference in the means between ICT usage and different teaching levels of Respondents. So the Null Hypothesis is rejected and alternate Hypothesis is accepted.

- Independent sample $t$ test Summary of extent of ICT usage among Gender

- Null Hypothesis: There is no significant difference in the means of ICT Usage across gender of respondents.

- Alternate Hypothesis: There is a significant difference in the means of ICT Usage across gender of respondents.

Table 8: $\mathrm{t}$ test Summary of extent of ICT usage among Gender

\begin{tabular}{lcccc}
\hline & Groups & $\mathrm{p}$ & $\mathrm{df}$ & $\mathrm{t}$ \\
Male & & 0.05 & 248 & 1.627 \\
Females & & 0.627 \\
\hline
\end{tabular}

At confidence level of $95 \%$ there is no significant difference in extent of ICT usage between genders. So the Null Hypothesis is accepted and alternate Hypothesis is rejected.

\section{Educational Implications}

- There is a significant difference in the means between ICT usage and different departments of Respondents. There is variation in terms of extent of usage implies that there are teachers who are more keen in some of the departments to adopt ICT. There should be more survey studies undertaken to find out which are the reasons that are influencing this trend. 
- There is a significant difference in the means between ICT usage and different age groups of Respondents. There should be various levels of introducing ICT in TLP. It is a wrong notion that each teacher has to adopt ICT in the same area. Every teacher can improvise content delivery through ICT. It need not be always complicated and software based. Simple things like downloading content material and presenting in class doesn't require much knowledge about ICT rather it needs an attitudinal shift.

- There is no significant difference in the means between ICT usage and different academic qualification of Respondents. This can help us to understand that it is not about how much and in what you are qualified but rather as a matter of fact a very useful piece of information which seeks to establish that anyone can be using any extent of ICT independent of their academic backgrounds.

- There is a significant difference in the means between ICT usage and different teaching levels of Respondents. This refers to ICT usage being incorporated non-uniformly at different levels of Education. Ideally it should be content driven not grade driven. Facilitators and curriculum designers should keep this in mind when framing methodologies of instructional delivery.

\section{Conclusion}

Innovation of ICT demands employees to keep pace with latest technological applications and be motivated to be open to accepting change in the modes of working. The skill set in modern times is so swiftly changing that it needs a lot of effort for an individual to stay current. Accessibility and Usage of ICT has started shaping up of individual's course of destiny in terms of career. Each Educational Institution is investing a big amount of its budget in terms of equipping the staff with basic to advanced training in ICT. An enormous amount is also being spent on Infrastructure to facilitate Teaching Learning post ICT implementation. Therefore to assure all this prove to be advantageous what is required is an optimistic attitude towards the adoption of new techniques and innovative best practices. 


\section{References}

Edwards, B. I. (2014). Science Teachers'attitudes towards ICTsupported Teaching as Predictors of Effective Learning in Nigerian High Schools. International Journal of Research in Social Sciences, 4(3), 540.

Elsaadani, M. (2012). Teaching staff attitude toward ICT: Is Gender a Factor? International Women Online Journal of Distance Education July, 1 (2), 1-10.

Goodwin, A. L., Low, E. L., Ng, P. T., Yeung, A. S., \& Cai, L. (2015).

Enhancing Playful Teachers' Perception of the Importance of ICT Use in the Classroom: The Role of Risk Taking as a Mediator. Australian Journal of Teacher Education, 40(4), 8.

Gruzd, A., Staves, K., \& Wilk, A. (2012). Connected scholars: Examining the role of social media in research practices of faculty using the UTAUT model. Computers in Human Behavior, 28(6), 2340-2350.

Khaled, K. (2014). The Effect of Information and Communications Technologies (ICT) in the Jordanian Universities. Information and Knowledge Management 4(12), pp. 122-132).

Khan, M., Hossain, S., Hasan, M., \& Clement, C. K. (2012). Barriers

to the Introduction of ICT into Education in Developing Countries: The Example of Bangladesh. Online Submission, 5(2), 61-80.

Larbi-Apau, J., \& Moseley, J. (2012). Computer attitude of teaching faculty: Implications for technology-based performance in higher education. Journal of Information Technology Education: Research, 11(1), 221-233.

Mainville, Y., \& Carey, S. (2013). Investigating Effective strategies of a Capacity Building Model for the Transformation of Teaching Practice.

Pretorius, R. W., Coetzee, R., de Jager, A. E., van Niekerk, H. J., Vlok, C. A., Hendrick, J. R. M., \&Potgieter, C. E. (2015). From Correspondence to Online Provisioning in Open and Distance Learning: Greening Implications versus Practical and Organisational Imperatives. In Implementing Campus Greening Initiatives (pp. 295-311). Springer International Publishing.

Quaye, F., Ametepe, W., \& Annan, N. K. (2015). The Impact of ICT on Teaching and Learning in Tertiary Institutions: A Case 
Study of Wisconsin International University College, Ghana. Journal of Information Engineering and Applications, 5(5), 8-14. Scherer, R., Siddiq, F., \&Teo, T. (2015). Becoming more specific: Measuring and modeling teachers' perceived usefulness of ICT in the context of teaching and learning. Computers \& Education, 88, 202-214.

Technology Enabled Learning | Government of India ... (n.d.). Retrieved from http://mhrd.gov.in/technology-enabledlearning-0

Voogt, J., Knezek, G., Cox, M., Knezek, D., \& ten Brummelhuis, A. (2013). Under which conditions does ICT have a positive effect on teaching and learning? A Call to Action. Journal of computer assisted learning, 29(1), 4-14. 